of Accounting Department, Vinnytsia National Agrarian University (21008, Vinnytsia, 3 Soniachna st., e-mail: lepetan_inna@i.ua)

ЛЕПЕТАН Инна Михайловна - кандидат экономических наук, доцент кафедры бухгалтерського учета, Винницкий национальный аграрный університет (ул. Солнечная, 3, г. Винница, 21008, e-mail: lepetan_inna@i.ua)

УДК 658.71/78

DOI: 10.37128/2411-4413-2020-3-13

АНАЛІТИЧНІ

ІНСТРУМЕНТИ ДЛЯ

КОНТРОЛЮ ТА

МОНІТОРИНГУ

ПУБЛІЧНИХ ЗАКУПІВЕЛЬ
МУЛИк Т.О., кандидат економічних наук, завідувач кафедри аналізу та статистики,

ТОМЧУК О.Ф., кандидат економічних наук, доцент кафедри аналізу та статистики,

МУЛИк Я. I., кандидат економічних наук, доцент кафедри аудиту та держсавного контролю, Вінницький національний аграрний університет, (м. Вінниця)

У статті досліджено аналітичні інструменти для контролю та моніторингу публічних закупівель. Визначено, щзо після запуску системи ProZorro та публікації значного масиву відкритих даних, в Украӥні з'явилося багато інструментів та сервісів, які допомагають аналізувати та моніторити публічні закупівлі та їхніх учасників. Інформація щзодо аналітичних інструментів для контролю та моніторингу публічних закупівель оновлюється за посиланням https://dozorro.org/tools. Охарактеризовано роль моніторингу у сфері публічних закупівель. Висвітлено підстави, відносно яких приймається рішення про початок моніторингу закупівлі. Визначено, щзо моніторинговий портал DoZоrro - це платформа, де кожен учасник системи може дати зворотній зв'язок державному замовнику чи постачальнику, обговорити та оцінити умови конкретної закупівлі, проаналізувати закупівлі окремого державного органу чи установи, підготувати та подати офіиійне звернення до органів контролю та багато іншого. Охарактеризовано різні можливості для будь-яких учасників закупівель, передбачені порталом DoZorro. Моніторинговий портал DoZorro містить: модулі аналітики, інструменти для замовників, інструменти для дослідження руху коштів, інструменти для дослідження учасників, інструменти судової практики, практики АМКУ, практики органів моніторинг. Кожен інструмент має свої особливості та можливості. Якщо підібрати правильний сервіс, можна знайти потрібну 
інформацію чи отримати бажаний результат набагато швидше і якісніше. Висвітлено та детально описано можливості публічного модуля аналітики. Він має великий перелік критеріїв, за якими можна відбирати закупівлі, плани, постачальників, замовників, та складається з певних додатків. Його структура представлена такими додатками: етапи планування та некоректні пункти планів, панель керівних органів, медичні закупівлі, етап закупівель ESCO. Висвітлено також можливості професійного модуля аналітики, медичного модуля аналітики, ризик-індикаторів DoZorro, закупівель COVID-19. Представлено порядок застосування індикаторів для формування черги ризикових процедур закупівлі. Визначено, щяо досліджувані інструменти дають можливість здійснювати аналіз закупівель в електронній системі й надають змогу в режимі реального часу відображати інформацію про оголочені закупівлі, про замовників, учасників, скарги, договори та іншу інформацію із центральної бази даних.

Ключові слова: аналітичні інструменти у сфері публічних закупівель, моніторинг, модулі аналітики, ProZorro, DoZorro.

Табл.: 1. Рис.: 5. Літ.: 15.

\title{
ANALYTICAL TOOLS FOR CONTROL AND MONITORING OF PUBLIC PROCUREMENT
}

\author{
MULYK Tetiana, \\ PhD in Economics, AssociateProfessor, \\ Headof theAnalysis and Statistics Department
}

TOMCHUK Olena, PhD in Economics, Associate Professor of Analysis and Statistics Department

\author{
MULYK Yaroslavna, \\ PhD in Economics, \\ Associate Professor of the Audit and State Control Department \\ Vinnytsia National Agrarian University \\ (Vinnytsia)
}

The article examines analytical tools for control and monitoring of public procurement. It was determined that after the launch of the ProZorro system and the publication of a significant amount of open data, many tools and services have appeared in Ukraine to help analyze and monitor public procurement and its participants. The information on analytical tools for controlling and monitoring public procurement is updated at https://dozorro.org/tools. The role of monitoring in the field of public procurement is described. The reasons for the decision to start monitoring procurement are highlighted. It is determined that the monitoring portal DoZorro is a platform where each participant of the system can give feedback to a state customer or supplier, discuss and evaluate the terms of a particular procurement, analyze the procurement of a particular government agency or institution, prepare and submit an official appeal to the regulatory authorities and much more. The opportunities for any procurement participants provided by the DoZorro portal are described. The DoZorro monitoring portal includes: analytics modules, tools for customers, tools for research of cash flow, tools for research of participants, tools of judicial practice, AMCU practice, and practice of monitoring authorities. Each tool has its own characteristics and capabilities. If you choose the right 
service, you can find the information you need, or get the desired result much faster and better. The capabilities of the public analytics module are given and detailed in detail. It has a large list of criteria by which you can select purchases, plans, suppliers, customers and consists of specific applications. Its structure is represented by the following appendices: planning stages and incorrect plan points, governing body panel, medical procurement, ESCO procurement stage. The capabilities of the professional analytics module, the medical analytics module, risk indicators DoZorro, procurement COVID-19 are also described. The procedure for using indicators to form a queue of risky procurement procedures is presented. It is determined that the researched tools allow to analyze purchases in an electronic system and allow to display in real time information about announced procurements, information about customers, participants, complaints, contracts and other information from the central database.

Key words: analytical tools in the field of public procurement, monitoring, analytics modules, ProZorro, DoZorro.

Tabl.: 1. Fig.: 5. Lit.: 15.

\title{
АНАЛИТИЧЕСКИЕ ИНСТРУМЕНТЫ ДЛЯ КОНТРОЛЯ И МОНИТОРИНГА ПУБЛИЧНЫХ ЗАКУПОК
}

\author{
МУЛЫК Т. А., \\ кандидат экономических наук, \\ заведующая кафедрой анализа и статистики
}

\author{
ТОМЧУК Е. Ф., \\ кандидат экономических наук, \\ доцент кафедры анализа и статистики
}

\author{
МУЛЫК Я. И., \\ кандидат экономических наук,
} доцент кафедры аудита и государственного контроля, Винницкий национальный аграрный университет, (2. Винница)

В статье исследованы аналитические инструменты для контроля и мониторинга публичных закупок. Определено, что после запуска системы ProZorro и публикации значительного массива открытых данных, в Украине появилось много инструментов и сервисов, помогающих анализировать и мониторить публичные закупки и их участников. Информащия об аналитических инструментах для контроля и мониторинга публичных закупок обновляется по ссылке https://dozorro.org/tools. Охарактеризована роль мониторинга в сфере публичных закупок. Освещены условия, в отношении которых принимается решение о начале мониторинга закупки. Определено, что мониторинговый портал DoZorro - это платформа, где каждый участник системы может дать обратную связь государственному заказчику или поставщику, обсудить и оченить условия конкретной закупки, проанализировать закупки отдельного государственного органа или учреждения, подготовить и подать официальное обращение в контролирующие органы и многое другое. Охарактеризованы возможности для любых участников закупок, предусмотренные порталом DoZorro. Мониторинговый портал DoZоrro содержст модули аналитики, инструменты для заказчиков, инструменть для исследования движения средств, 
инструменты для исследования участников, инструменты судебной практики, практики АМКУ, практики органов мониторинг. Каждый инструмент имеет свои особенности и возможности. Если подобрать правильный сервис можно найти нужную информацию, получить желаемый результат гораздо быстрее и качественнее. Освещены и подробно описано возможности публичного модуля аналитики. Он имеет большой перечень критериев, по которым можно отбирать закупки, планы, поставщиков, заказчиков и состоит из определенных приложений. Его структура представлена следующими приложениями: этапы планирования и некорректные пункты планов, панель руководящих органов, медицинские закупки, этап закупок ESCO. Освещены также возможности профессионального модуля аналитики, медииинского модуля аналитики, риск-индикаторов DoZorro, закупок COVID-19. Представлены порядок применения индикаторов для формирования очереди рисковых прочедур закупки. Определено, что исследуемье инструменты дают возможность осуществлять анализ закупок в электронной системе и дают возможность в режиме реального времени отображать информацию об объявленных закупках, информацию о заказчиках, участников, жалобы, договоры и другую информачию из центральной базы данных.

Ключевые слова: аналитические инструменты в сфере публичных закупок, мониторинг, модули аналитики, ProZorro, DoZorro.

Табл.: 1. Рис.: 5. Лит.: 15.

Постановка проблеми. У сучасних умовах господарювання здійснення першорядної функції публічних закупівель (матеріальне забезпечення суспільних потреб) досягається шляхом створення конкурентного середовища, також вагомими чинниками $є$ забезпечення прозорості, запобігання виявам корупції та результативного використання коштів. Як підтверджує національна та міжнародна практика публічних закупівель, досягнення цих цілей допустиме лише у разі встановлення єдиних для всієї країни прозорих процедур закупівель та створення системи закупівель, яка включає: законодавче, інституційне та інформаційне забезпечення.

Міністерством розвитку економіки, торгівлі та сільського господарства України та Державним підприємством "Прозорро" створено інформаційні ресурси, які забезпечують безкоштовний доступ усіх суб'єктів сфери до методологічних, навчальних, роз'яснювальних матеріалів, узагальнених листів, безкоштовних консультацій, статей та відеоматеріалів щодо застосування закупівельного законодавства та функціонування електронної системи публічних закупівель[1].

За час реформування сфери публічних закупівель у співпраці 3 міжнародними донорськими організаціями, суб'єктами сфери публічних закупівель, громадськими організаціями, волонтерами було створено низку корисних аналітичних інструментів, які сприяють громадському моніторингу та мають широкий функціонал. Такі інструменти дають можливість здійснювати аналіз закупівель в електронній системі i надають можливість у режимі реального часу відображати інформацію про оголошені закупівлі, про замовників, учасників, скарги, договори та іншу інформацію з центральної бази даних. Розроблено також окремі інструменти, завдяки яким є можливість вільно 


\section{EФМ}

http://efm.vsau.org/

та безкоштовно досліджувати інформацію про використання публічних коштів, а також виявляти зв'язки та можливу змову у закупівлях між учасниками, організаторами тендерів, потенційними постачальниками тощо [1], що визначає актуальність теми.

Аналіз останніх досліджень та публікацій. Різноманітним питанням здійснення механізму публічних закупівель присвячено праці таких вітчизняних та зарубіжних учених, як Я. Горбатюк, Д. Батуєва, О. Декалюк, О. Крітенко В. Міняйло, Т. Затонацька, О. Клювак, Я. Петруненко, С. Левченко, А. Сошніков, В. Малолітнева, І. Дрозд, Ф. Узунов, Д. Мартинович, Ю. Фалко, Л.Федоровський, Н. Здирко [3],О. Письменна, Х. Зелінська [4], С. Левон [14], Т. Ратушняк [15] та інші.

Питанням методики, методології та організації економічного аналізу, зокрема в державному секторі, присвячено дослідження багатьох учених та практиків: М. Болюх, О. Богданюк, О. Олійник, С. Левицька, І. Лазаришина, Д. Грицишин, Ю. Цал-Цалко, В. Савчук, А. Заросило, Т. Мулик [2], О. Томчук та інші. Низку досліджень проведено 3 визначення особливостей організації та методики аналізу певних об’єктів, таких як основні засоби, запаси, доходи, видатки, фінансові результати тощо. Проте, не зважаючи на численні дослідження науковців із питань організації аналізу в державному секторі, значна кількість проблем вимагає подальших уточнень через нове законодавство, зміни в організації діяльності тощо. Останнім часом актуалізуються питання, пов'язані з функціонуванням, організацією здійснення, оцінкою та аналізом публічних закупівель. Деякі питання аналізу публічних закупівель досліджували М. Письменна, Д. Мартинович, I. Парасій-Вергуненко, В. Міняйло, Т. Мулик [2], Н. Здирко [2], проте питання аналітичних інструментів контролю та моніторингу публічних закупівель потребує грунтовнішого дослідження.

Мета статті. Дослідження аналітичних інструментів для контролю та моніторингу публічних закупівель, оцінка моніторингового порталу DoZorro.

Виклад основного матеріалу. Поміж важливих проблем економічного розвитку країни, особливу нішу займають питання поліпшення ефективності використання державних ресурсів для забезпечення стійкого розвитку національної економіки та іiї безпеки. Одним із методів державного регулювання національної економіки $є$ функціонування публічних закупівель. Їм належить неабияка роль у значенні перспективного макроекономічного важеля, за допомогою якого допустиме формування повноцінного конкурентного середовища, здійснення стабілізаційної політики в країні тощо.

Публічні закупівлі вважаються інструментом, що посилює звітність та прозорість у сфері публічного управління та адміністрування, знижує рівень корупції під час здійснення закупівель та поліпшує бізнес-клімат у державі. Проведення публічних закупівель завжди активно обговорювалася широким колом зацікавлених осіб, і за останній час увага до питань публічних закупівель 
лише зросла [2]. Публічні закупівлі - це придбання товарів, робіт і послуг, що закуповуються замовником у межах єдиної процедури закупівлі, щодо яких учасникам дозволяється подавати тендерні пропозиції або пропозиції на переговорах [3].

Позитивним $є$ те, що Україна цьогоріч набрала 97,05 балів зі 100 можливих і здобула першість у Transparent Public Procurement Rating_(Рейтингу прозорості публічних закупівель). Друге та третє місце посіли Молдова $(92,81)$ і Колумбія $(91,77)$ відповідно. Найгірший результат у Таджикистану — він отримав 37,88 балів (рис. 1).

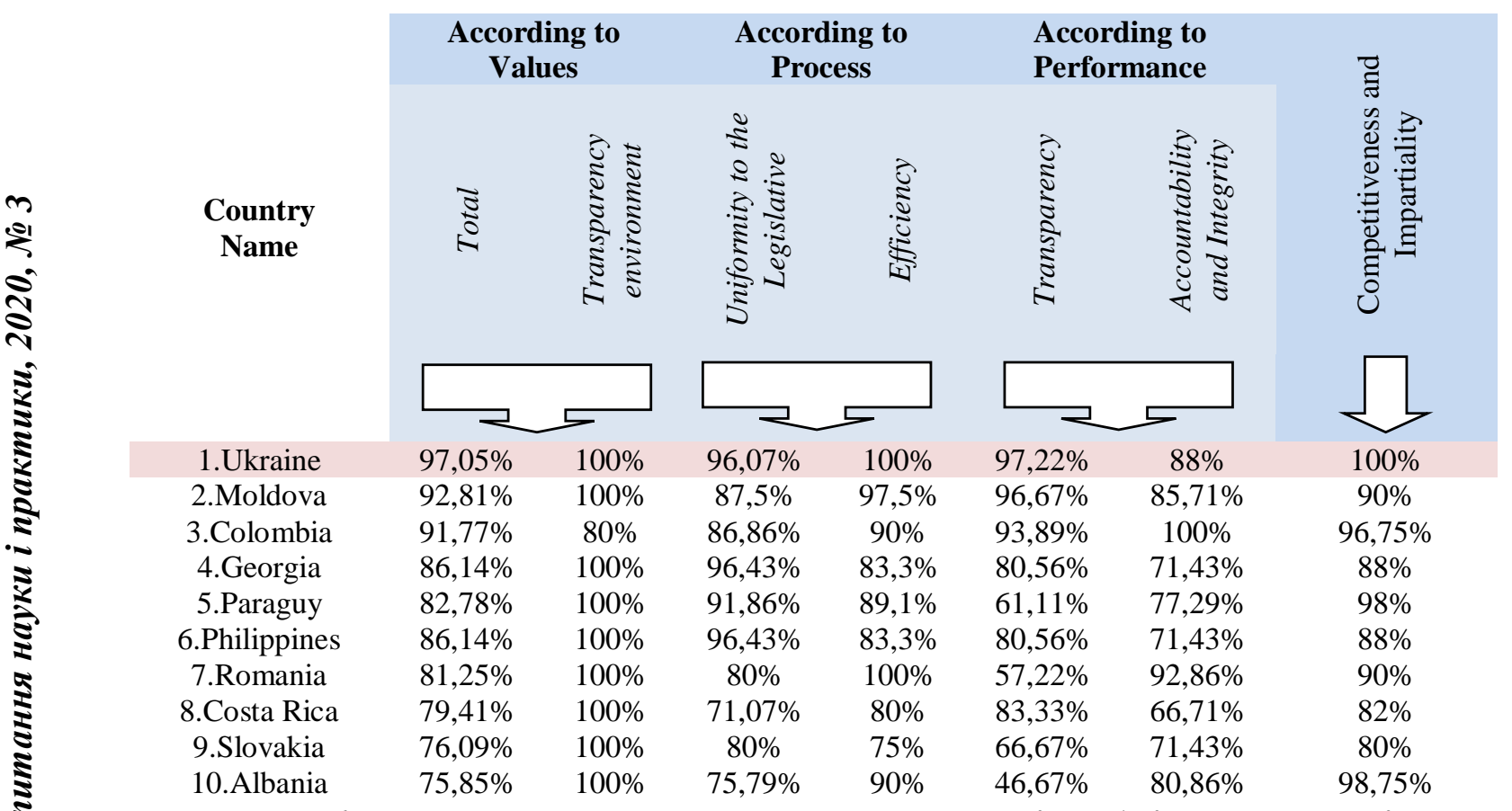

\section{Рис 1. Рейтинг України щодо прозорості публічних закупівель} Джерело: [4]

Першість у рейтингу — це вагоме і приємне досягнення, проте є ще багато над чим працювати.

Як відзначає менеджер програми інноваційних проєктів X. Зелінська, поперше, Україні варто продовжити діджиталізацію публічних закупівель. Наше майбутнє неможливе без електронного документообігу, тож вдосконалювати цей процес треба вже зараз. По-друге, правила для чесних закупівель не матимуть сили без санкцій за їх недотримання i, на жаль, контролю 3 боку Держаудитслужби, який на разі $\epsilon$ недостатнім. Згідно 3 останніми дослідженнями, аудитори перевіряють лише $0,2 \%$ публічних закупівель в Україні. Не потрібно обмежувати конкурентні ринки та надавати преференції кільком окремим виробникам [4].Важливе значення в системі публічних закупівель відіграють різні інструменти та сервіси. Після запуску системи ProZorro та публікації значного масиву відкритих даних, в Україні з'явилося багато інструментів та сервісів, які допомагають аналізувати та моніторити 
публічні закупівлі та їхніх учасників. Інформація щодо аналітичних інструментів для контролю та моніторингу публічних закупівель оновлюється за посиланням https://dozorro.org/tools [5].Прагнучи забезпечити відповідне дотримання принципів добросовісності та прозорості та схвалювати обгрунтовані рішення щодо розвитку системи публічних закупівель, уряди більшості країн здійснюють контроль за цією системою. Це нерідко робиться через створення окремого органу 3 такою функцією. Цей орган може входити до складу державної адміністрації (наприклад, бюро державних закупівель Литви або Польщі) або незалежної організації (наприклад, наглядова рада 3 питань державних закупівель - El Observatorio de Contratación Pública, Іспанія). Згідно 3 визначенням програми SIGMA, моніторинг державних закупівель зазвичай включає такі види діяльності, як збір, аналіз, поширення даних тощо [6].

Роль моніторингу у сфері публічних закупівель [6]:

- оцінити, як розвивається система публічних закупівель загалом і в якому напрямку вона рухається, і тим самим надати значущу інформацію, яка має важливе значення для розробки правил;

- визначити необхідність будь-яких змін в системі;

- встановити короткострокові і довгострокові пріоритети і оцінити, чи були вони досягнуті;

- проаналізувати потенційний вплив альтернативних рішень;

- надати рекомендації щодо політики закупівель та реалізації рішень;

- надати інформацію, яка стосується рішень, прийнятих іншими керівниками.

Для забезпечення того, щоб моніторинг давав значущі результати, необхідно виконати низку умов. По-перше, політичні цілі і завдання системи державних закупівель повинні бути узгоджені в часі, оскільки в іншому випадку буде важко порівнювати результати, отримані в процесі моніторингу. По-друге, важливе значення має наявність надійних і достовірних даних. По-третє, ефективний контроль вимагає від співробітників, які займаються моніторингом, хороших аналітичних навичок і навичок складання звітності. Вони повинні знати, яка інформація є корисною, як збирати цю інформацію, як чинити зі зібраними даними, як робити висновки і як представляти результати, отримані в ході моніторингу. По-четверте, ефективність моніторингу залежить від офіційної підтримки, керівництва та дій [6].

Рішення про початок моніторингу закупівлі, відповідно до частини 2 статті 7-1 Закону № 922 [7], приймає керівник органу державного фінансового контролю або його заступник за наявності однієї або декількох із таких підстав:

наявні дані автоматичних індикаторів ризиків. Відбір відбувається в автоматичному режимі за заданими наперед параметрами. Тобто унеможливлює вплив людського чинника;

отримана інформація від органів державної влади, органів місцевого самоврядування про наявність ознак порушення законодавства у сфері 
публічних закупівель;

засоби масової інформації надали повідомлення, що містять відомості про наявність ознак порушення;

орган державного фінансового контролю виявив ознаки порушення в інформації, оприлюдненій в електронній системі закупівель. Наприклад, за результатами проведених кількох моніторингів закупівель виявлені факти типових порушень замовником вимог законодавства у сфері закупівель, що свідчать про ймовірність допущених аналогічних порушень під час інших процедур закупівель. І це підтверджує інформація, оприлюднена за відповідними процедурами в електронній системі закупівель;

громадські об'єднання оприлюднили інформацію про порушення, виявлені за результатами громадського контролю у сфері публічних закупівель відповідно до статті 9 Закону № 922 [7].

Отже, моніторинговий портал DoZorro - це платформа, де кожен учасник системи може дати зворотній зв'язок державному замовнику чи постачальнику, обговорити та оцінити умови конкретної закупівлі, проаналізувати закупівлі окремого державного органу чи установи, підготувати та подати офіційне звернення до органів контролю та багато іншого. Порталом DOZORRO передбачені різні можливості для будь-яких учасників закупівель (рис. 2).

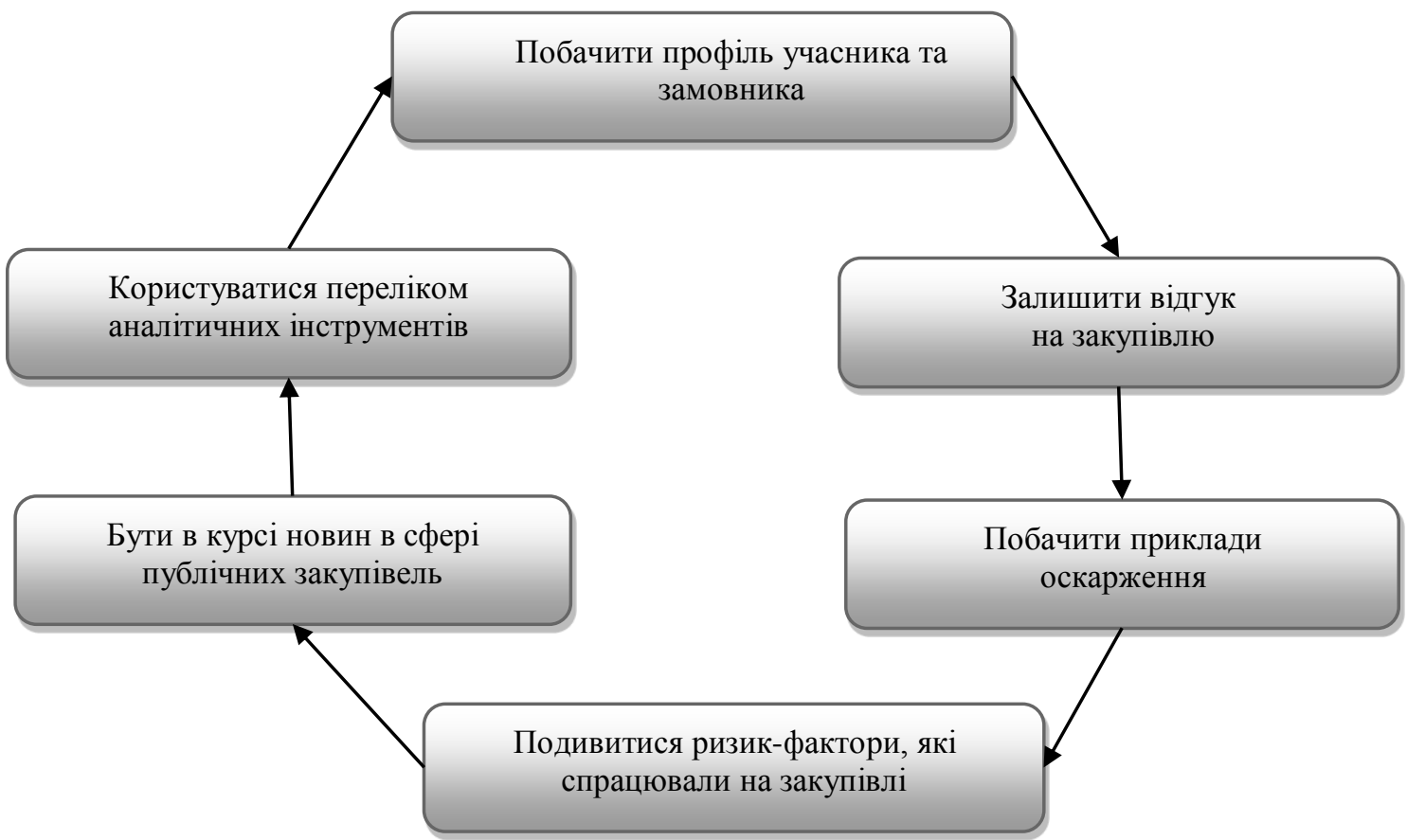

\section{Puc. 2. Можливості порталу DOZORRO}

Джерело: побудовано авторами на основі інформащії представленої на порталі DOZORRO [5]

Його інтерфейс представлено на рис. 3.

DOZORRO формує базу даних відгуків на закупівельні процедури, які 
відбуваються у електронній системі публічних закупівель ProZorro. Інформація про конкретні закупівлі в DOZORRO потрапляє автоматично з бази даних ProZorro. Відгук на сторінці закупівлі може залишити будь-який авторизований користувач мережі. Відгук містить якісну оцінку конкретного тендеру (опис проблем, скарги, подяки тощо) та кількісну — автор відгуку оцінює тендер від одного до п’яти за такими характеристиками [8]:

- оцінка умов закупівлі;

- оцінка взаємодії замовника із учасниками;

- оцінка процесу кваліфікації;

- оцінка виконання замовником умов договору.

Інформація 3 відгуків $\epsilon$ сигналом для дослідження ситуації 3 боку громадських організацій, які є членами DOZORRO-спільноти. У разі виявлення порушень громадські монітори скеровують звернення до замовників (організатори тендерів), їхніх керівних органів (установи у підпорядкуванні яких перебувають замовники), органів контролю (Держаудитслужба, Рахункова палата), правоохоронних органів (ДЗЕ НП,НАБУ) або АМКУ. За допомогою юридичного та медійного тиску громадські організації намагаються досягти усунення порушень закону «Про публічні закупівлі» [7] у конкретному тендері та притягнути винних до адміністративної або кримінальної відповідальності [8]:

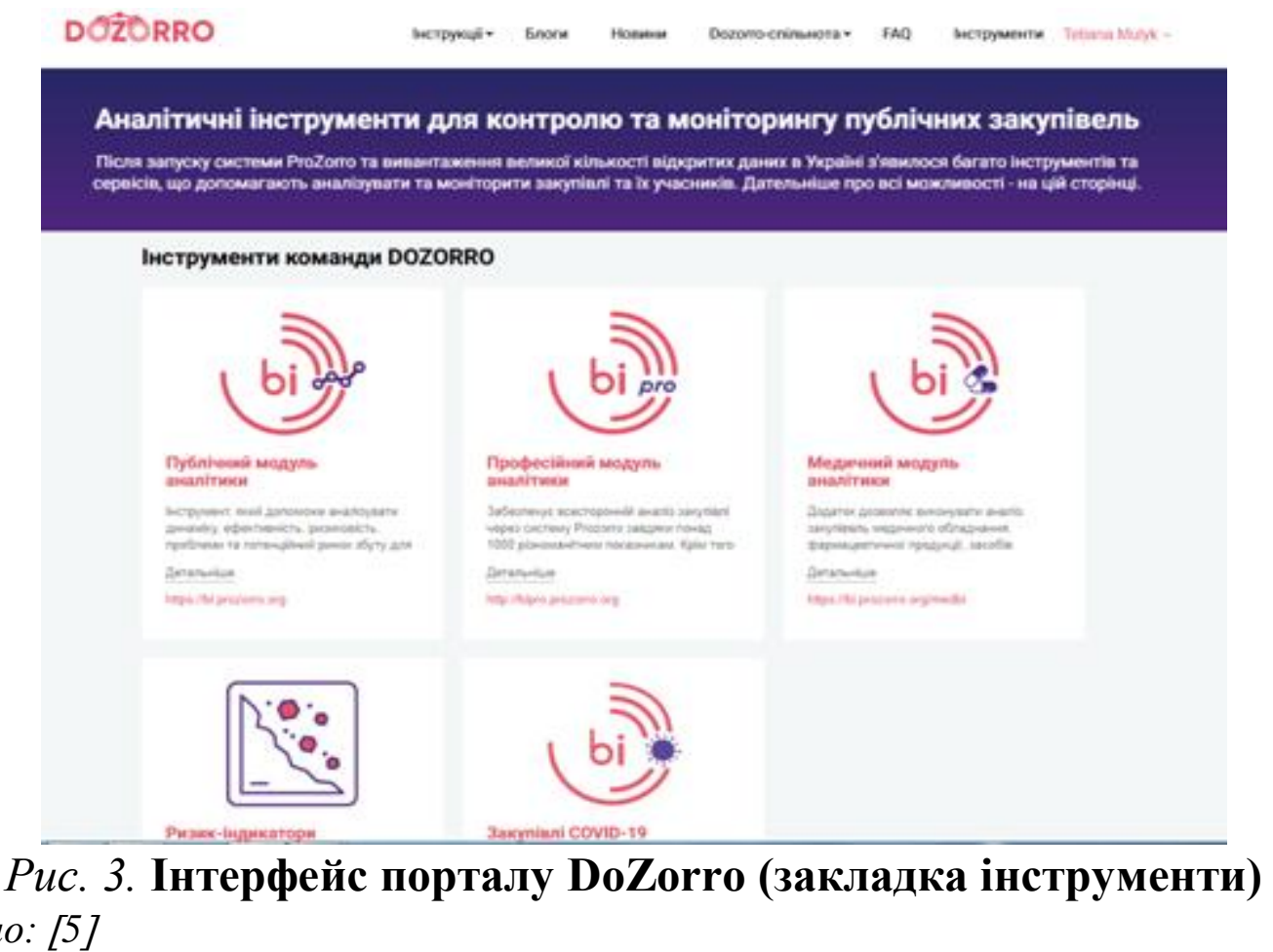

Джерело: [5]

Інструменти команди DOZORRO містять:

- публічний модуль аналітики;

- професійний модуль аналітики;

- медичний модуль аналітики; 
- ризик-індикатори DOZORRO;

- закупівлі COVID-19;

- Веб-портал Уповноваженого органу;

- Clarity Project;

- Закупівлі;

- Антикорупційний монітор;

- Пошук та відстеження додаткових угод в ProZorro;

- Антикорупційна карта ремонтів;

- Аналітика закупівель ESCO; CoST (Construction Sector Transparency Initiative). Прозора інфраструктура;

- Портал моніторингу витрат на будівництво і ремонт автомобільних доріг України;

- Завантаження документів учасників.

Інструменти для замовників:

- Методологія створення тендерної документації;

- Схеми процесів закупівлі ProZorro;

- Рахуємо уповноважених осіб;

- Калькулятор визначення зміни ціни на природний газ;

- Конструктор нецінових критеріїв.

Дослідження руху коштів:

- Є-дата;

- Пошуково-аналітична система 007.

Дослідження учасників:

- Сдиний державний реєстр;

- YouControl;

- Opendatabot;

- CONTR AGENT.

Судова практика, практика АМКУ, практика органів моніторингу:

- Суд на долоні;

- Clarity APP;

- Єдиний державний реєстр судових рішень «Бабуся».

Характеристика основних аналітичних інструментів у системі публічних закупівель наведена в таблиці 1.

Одним із важливих та інформативних аналітичних інструментів $\epsilon$ публічний модуль аналітики (рис. 4). Він містить інформацію про закупівлі через систему Prozorro з 2015 року.

Модуль дозволить замовникам знайти типову документацію, перевірити постачальників та додатково оцінити рівень власної ефективності. Учасники зможуть оцінити ринок, знайти нові ринки збуту та отримати нових партнерів. Журналісти зможуть знайти цікаві історії чи перевірити слова політиків. Громадські організації за допомогою модуля знайдуть зради та правопорушення. 
Модуль дозволить виокремити неефективність у сфері публічних закупівель, а органи контролю зможуть відстежити, як працюють підпорядковані організації і в чому їм потрібна допомога.

Основні можливості публічного модуля аналітики наведено на рис. 5.

Публічний модуль аналітики в онлайн-режимі показує усі закупівлі, які проводяться через електронну систему Prozorro. BI ProZorro має великий перелік критеріїв, за якими можна відбирати закупівлі, плани, постачальників/ замовників та складається з певних додатків:

1. Етапи планування та некоректні пункти планів:

Етап планування (оголошення із 2019 р) - Planning stage (announcement from 2019) - дозволяє виконувати аналіз планів закупівель за два останні роки та додатків до них із застосуванням вибірки по таких статичних даних: \% виконання планів, \% планів зі змінами, параметри виконання, \% виключених планів (тих, в яких очікувана вартість «0» і по яких не планується проведення закупівлі тощо).

Таблиия 1

\section{Характеристика основних аналітичних інструментів у системі} публічних закупівель

\begin{tabular}{|c|c|c|}
\hline $\begin{array}{l}\text { Аналітичні } \\
\text { інструменти }\end{array}$ & Адреса інструментів & Характеристика інструментів \\
\hline $\begin{array}{l}\text { Публічний } \\
\text { модуль } \\
\text { аналітики }\end{array}$ & https://bi.prozorro.org & $\begin{array}{l}\text { Інструмент, який допоможе аналізувати динаміку, } \\
\text { ефективність, ризиковість, проблеми та потенційний ринок } \\
\text { 3буту для тендерів } 32015 \text { року }\end{array}$ \\
\hline $\begin{array}{l}\text { Професійний } \\
\text { модуль } \\
\text { аналітики }\end{array}$ & http://bipro.prozorro. org & $\begin{array}{l}\text { Забезпечує всесторонній аналіз закупівлі через систему } \\
\text { РroZorro завдяки понад } 1000 \text { різноманітним показникам. Крім } \\
\text { того дає змогу налаштувати під свої потреби таблиці та графіки, } \\
\text { або навіть створити власні показники. }\end{array}$ \\
\hline $\begin{array}{l}\text { Медичний } \\
\text { модуль } \\
\text { аналітики }\end{array}$ & $\begin{array}{l}\text { https://bi.prozorro.org/med } \\
\text { bi }\end{array}$ & $\begin{array}{l}\text { Додаток дозволяє виконувати аналіз закупівель медичного } \\
\text { обладнання, фармацевтичної продукції, засобів особисто } \\
\text { гігієни в різних розрізах. До даних відносяться: довідники, } \\
\text { інформація по тендерах, пропозиції учасників та інше. }\end{array}$ \\
\hline $\begin{array}{l}\text { Ризик- } \\
\text { індикатори } \\
\text { DOZORRO }\end{array}$ & $\begin{array}{l}\text { https://dozorro.org/blog/po } \\
\text { rtal-dozorro-novi- } \\
\text { mozhlivosti }\end{array}$ & $\begin{array}{l}\text { Інструмент підсвічує, які ризики спрацювали у обраній } \\
\text { процедурі або допомагає знайти процедури, у яких спрацював } \\
\text { обраний ризик чи комбінація ризиків. }\end{array}$ \\
\hline $\begin{array}{c}\text { Закупівлі } \\
\text { COVID-19 }\end{array}$ & https://covid.dozorro. org/ & $\begin{array}{l}\text { Інструмент для швидкого аналізу антикорона-вірусних } \\
\text { закупівель у РroZorro. Збирає, візуалізує і допомагає обробляти } \\
\text { дані про публічні закупівлі для боротьби з COVID-19. За } \\
\text { допомогою нього можна досліджувати закупівлі за різними } \\
\text { параметрами: географією, у різні проміжки часу, за певними } \\
\text { групами товарів і навіть за конкретним замовником (покупцем) } \\
\text { або постачальником (продавцем). }\end{array}$ \\
\hline
\end{tabular}

Джерело: побудовано авторами на основі інформаиї представленої на порталі DOZORRO [5].

Його структура представлена наступними додатками:

Некоректні пункти плану (опубліковані з 2019 р) - дозволяє виконувати аналіз некоректних пунктів планів закупівель та додатків до них із застосуванням вибірки за такими статичними даними: некоректна дата доставлення, некоректна очікувана вартість, некоректна дата оголошення, некоректний предмет закупівлі, 
відсутність КЕКВ тощо.

Публічний модуль аналітики ВІ ПЕРЕХІд НА модУЛ!

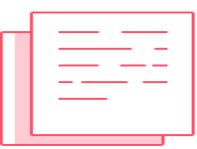

Перелік інформаційних полів в Публічному ВІ

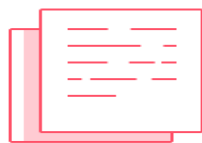

Iсторії
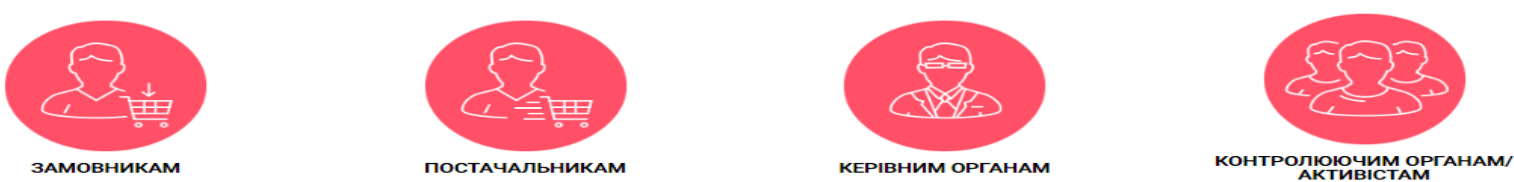

Рис. 4. Фрагмент «Публічний модуль аналітики»

Джерело: [5]

$m$

1. Оцінка потенційного ринку

- Оцінка потенційного об'єму ринку державних закупівель для постачальника

- Оцінка привабливості публічних закупівель та аналіз цін за одиницю товару в системі

2. Аналіз конкуренції в успішно завершених закупівлях

- Вибір найвигіднішого тендеру

- Пошук актуальних планів закупівель

3. Оцінка ризик-факторів

- Аналіз статусів договорів за допомогою карточки учасника

- Аналіз скарг до Колегії Антимонопольного комітету України

\section{Рuc. 5. Можливості публічного модуля аналітики}

Джерело: побудовано авторами на основі інформаџії представленої на порталі DOZORRO [5]

\section{1. Якісна тендерна документація \\ - Пошук укладених договорів в системі ProZorro за певний проміжок часу \\ 2. Оцінка договорів, що потенційно під загрозою \\ • Проблеми з постачальниками}

3. Аналіз окремого постачальника або майбутнього переможця

- Сума податкового боргу учасника, статус юридичної особи та інші показники

4. Виправлення помилок

- Помилки в річних планах закупівель

- Показники ефективності 
2. Панель керівних органів - дозволяє відстежувати тенденції у закупівлях ієрархій організаторів та виявляти останні важливі події у закупівлях за поточний і попередній рік.

3. Медичні закупівлі (Medical purchasing) - дозволяє виконувати аналіз закупівель медичного обладнання, фармацевтичної продукції, засобів особистої гігієни в різних розрізах.4. Етап закупівель ESCO (Purchasing stage ESCO) дозволяє виконувати аналіз закупівель енергосервісу в різних розрізах: лоти, організатори, учасники, скарги, статуси процедур тощо.

Ще одним аналітичним інструментом у сфері публічних закупівель $\epsilon$ професійний модуль аналітики. Це більш розширена та складніша версія аналітики, однак, із обмеженою кількістю аккаунтів доступу. У ній містяться зведені таблиці, індикатори ризику, програмування власних вибірок. Додаток дозволяє виконувати аналіз закупівель у всіх наявних розрізах: товари та всі наявні угруповання (групи, класи тощо), тендери (відкриті, завершені, невдалі), лоти, організатори, учасники, за будь-який обраний період будь-якої комбінації відборів (товарів, тендерів, учасників і т.п.). Тут можна займатись аналізом договорів закупівель та зберігати заклади відборів, чого немає у публічному модулі. Коли потрібно займатись комплексним аналізом, краще та зручніше це дозволяє саме цей модуль [9].

Саме звідси можна вивантажити дані у форматі Excel. Також цей модуль дозволяє проводити ретельніший аналіз зі ще більшої кількості розрізів, будувати свої об'єкти чи графіки, окрім наявних, адже об'єкти публічної версії зафіксовані. Тут більш зручно аналізувати зв'язки між конкурентами, частки участі певного учасника із замовниками, ризик індикатори, контракти та переможців, аналізувати ходи аукціонів на системному рівні [9].

Медичний модуль аналітики містить інформацію про медичні закупівлі і дозволяє виконувати аналіз даних про них. Медичні закупівлі - це процедури, які стосуються закупівель медичного обладнання, фармацевтичної продукції, засобів особистої гігієни в різних розрізах. До них належать: довідники, інформація про тендери, пропозиції учасників та інше. Модуль дозволяє замовникам, керівним та правоохоронним органам аналізувати закупівлі розпорядників коштів, знаходити проблемні місця i шляхи їх вирішення. Учасники чи потенційні учасники зможуть оцінити ринок, ціни на товари, замовників та конкурентів, щоб приймати в майбутньому більш ефективні рішення [5].

Система ризик індикаторів також належить до аналітичних інструментів (табл. 1) допомагає швидко оцінити як окремий тендер, так і замовника на предмет ризику неефективного проведення процедури чи обмеження конкуренції. Учасники зможуть оцінити надійність замовника, замовники виявити типові проблеми у своїх закупівлях, а громадяни - зрозуміти, як проводять закупівлі державні установи, що надають їм послуги. Система реагує на 35 ризик-індикаторів. Зокрема, порушення процедури проведення торгів, 
відсутність повноважень суб'єкта торгів, відсутність цифрових підписів, перевищення термінів розгляду, відсутність укладеного договору, відсутність завантажених тендерних документів, відсутність опису предмету закупівлі, велика кількість лотів у тендері тощо.

Усі індикатори розподіляються за типом ризиків:

- проблема в умовах тендеру;

- підозрілі учасники тендеру;

- підозріле проведення тендеру;

- підозріле виконання договору;

- негативні відгуки або неякісна комунікація.

Станом на 31.08.2016 ризик індикатори охоплюють усі процедури закупівель у статусі «Завершено», що оголошені 31 січня 2016 року із очікуваною вартістю від 1 млн грн. Містить наступні вкладки: головна, тендери, m карта ризиків [5].

На головній сторінці, міститься огляд ризик індикаторів, які спрацьовують กิ $\mathrm{y}$ закупівлях ProZorro найчастіше і також оцінку ризикованості закупівель найбільших організаторів торгів як за кількістю, так і за очікуваною вартістю.

Тендери за ризик індикатором - відображено інформацію для кількох закупівель (для торгів - рівень тендеру) має сенс кожен ризик індикатор. Відображено також таблицю із ТОП 10 замовників (за очікуваною вартістю) $\mathrm{i}$ ризик індикаторів. На перехрещені замовника й індикатора можна побачити кількість закупівель, у яких спрацював обраний індикатор або сумарна очікувана вартість закупівель, де спрацював обраний індикатор (залежно від положення перемикача).

Карта ризиків - дає можливість переглянути для скількох процедур і на яку загальну очікувану вартість спрацював відповідний ризик-індикатор за відібраними замовниками. Складається із двох елементів: відборів і таблиці ризиків.

На основі даних від ризик-індикаторів Держаудитслужба України приймає рішення про проведення моніторингу. Окрім сигналів від системи ризикіндикаторів, приводом для моніторингу можуть стати звернення від громадських організацій, органів влади та місцевого самоврядування або ж інформація у ЗМІ. На відміну від розгляду скарг Антимонопольним комітетом України, початок моніторингу Держаудитслужбою не зупинятиме хід закупівлі [10].

Моніторинг $є$ превентивною мірою і спрямований на попередження порушень. До замовників, які вчасно реагуватимуть на зауваження аудиторів, штрафні санкції не застосовуватимуться. Якщо ж замовник так і не усуне виявлені під час моніторингу порушення, то аудитори можуть ініціювати проведення комплексної перевірки та накласти штрафи. Весь процес моніторингу однієї процедури триває до 15 робочих днів. Усі дії в рамках моніторингу будуть публічними, що дозволить зрозуміти, наскільки ефективно працюють аудитори та чи не зловживають службовим становищем [10]. 
Для забезпечення виконання повноважень державного фінансового контролю у сфері закупівель шляхом проведення моніторингу закупівлі Держаудитслужбою затверджено наказ від 11.09.2018 №196 «Про затвердження методики визначення автоматичних індикаторів ризиків, їх переліку та порядку застосування» [11]. Наказом визначено механізм визначення автоматичних індикаторів ризиків та порядок їх застосування.

Порядок застосування індикаторів для формування черги ризикових процедур закупівлі полягає в тому, що [12]:

1. Ризик-система щодня здійснює автоматичний розрахунок індикаторів за процедурами закупівель, які проводяться замовниками в електронній системі закупівель, формує чергу та показує iї в персональному кабінеті.

2. Ризик-система після спрацювання одного або кількох індикаторів за окремою процедурою закупівлі автоматично здійснює підрахунок загальної умовної ваги індикаторів.

3. У разі спрацювання індикатора (індикаторів) за конкретною процедурою закупівлі (або окремим лотом) та залежно від загальної умовної ваги цих індикаторів ризик-система закупівель автоматично присвоює процедурі закупівлі один із таких рангів ризику:

- 1 ранг ризику - високий рівень ризику;

- 2 ранг ризику - помірний рівень ризику;

- 3 ранг ризику - низький рівень ризику.

Діапазон значень загальної умовної ваги спрацьованих індикаторів кожного рангу ризику встановлює Держаудитслужба за погодженням 3 Мінекономіки.

4. Усередині кожного з рангів ризику процедури закупівлі, щодо яких спрацювали індикатори, розташовуються залежно від загальної умовної ваги.

5. Кожній процедурі закупівлі, щодо якої спрацювали індикатори, ризиксистема присвоює середньозважену умовну вагу, яка визначена з урахуванням загальної умовної ваги та очікуваної вартості процедури закупівлі у відповідному рангу ризику.

6. Ризик-система заносить до персонального кабінету у чергу з кожного рангу ризику фіксований відсоток процедур закупівель, що мають найвищу середньозважену умовну вагу. Величину відсотка процедур, що мають відображатися у черзі, встановлює Держаудитслужба за погодженням 3 Мінекономіки.

7. Процедури закупівлі ризик-система автоматично розташовує в черзі пропорційно, починаючи від процедур, що віднесені до 1 рангу ризику та мають найбільшу середньозважену умовну вагу, до тих, що віднесені до 3 рангу ризику та мають найменшу середньозважену умовну вагу.

8. Під час обрання органом державного фінансового контролю процедур закупівель для здійснення моніторингу насамперед обирають процедури закупівлі, що мають найвищий пріоритет у черзі. 
9. Під час перегляду процедури закупівлі, що внесена до черги, для прийняття рішення щодо їі обрання органом державного фінансового контролю для моніторингу в персональному кабінеті надається можливість переглянути процедуру закупівлі та перелік індикаторів, що спрацювали за цією процедурою, створити чернетку моніторингу закупівлі в електронній системі закупівлі або перенести посилання на процедуру закупівлі з черги до архіву.

10. Посилання на процедуру закупівлі автоматично виключається з черги ризикових процедур закупівлі та переноситься до архіву в персональному кабінеті у таких випадках:

- за процедурою закупівлі розпочато моніторинг;

- оприлюднено звіт про виконання договору;

- процедура закупівлі скасована або визнана такою, що не відбулася;

- усі порушення, за якими спрацювали індикатори, усунено.

m Використання автоматичних індикаторів ризику дає можливість خ. автоматично здійснювати вибір процедур закупівель, що містять ознаки حิ порушень законодавства у сфері публічних закупівель [12].

Отже, використання інформаційних електронних мереж дозволяє підвищити рівень прозорості публічних закупівель і покращує зв’язок між учасниками тендеру і його організаторами [13], а зазначені інструменти дають можливість здійснювати аналіз закупівель в електронній системі й надають змогу в режимі реального часу відображати інформацію про оголошені закупівлі, інформацію про замовників, учасників, скарги, договори та іншу інформацію із центральної бази даних. Однак, подальше удосконалення інструментарію забезпечення прозорості електронних публічних закупівель стане важливим кроком на шляху до вільного та безоплатного дослідження інформації про використання бюджетних коштів, а також допоможе виявляти зв'язки та можливу змову у закупівлях між учасниками, організаторами тендерів, потенційними постачальниками [14].

Висновки. Результати проведеного дослідження демонструють, що в Україні створено моніторинговий портал DoZorro - платформу, де кожен учасник може дати зворотній зв'язок державному замовнику чи постачальнику, обговорити та оцінити умови конкретної закупівлі, проаналізувати закупівлі окремого державного органу чи установи, підготувати та подати офіційне звернення до органів контролю та багато іншого. Практика показує, що моніторинговий портал DoZorro має необхідні аналітичні інструменти для виявлення порушень під час проведення тендерів, оцінки угод та оскарження сумнівних закупівель. Вони дають можливість здійснювати аналіз закупівель в електронній системі в режимі реального часу та відображати інформацію про оголошені закупівлі, замовників, учасників, скарги та укладені договори.

Перевагами ProZorro є: закупівлі за державні кошти відбуваються в онлайн-режимі; будь-яка особа може бути віртуально присутньою на аукціоні закупівлі; спроба провести корумпований тендер одразу отримує розголос; 
система назавжди зберігає історію редагувань та дає можливість подивитися видалені документи; процес вибору переможця є зрозумілим та публічним; будьякий учасник торгів у режимі он-лайн може подивитися перелік компаній учасників та подати скаргу; у систему викладається повна інформація про товар, послугу або роботи переможця, включно з укладеним договором; мінімальний пакет довідок при подачі пропозиції; електронний документообіг; зручний інтерфейс для подання пропозицій; постійна підтримка професійними колцентрами [15].

Моніторинговий портал DoZorro містить: модулі аналітики, інструменти для замовників, інструменти для дослідження руху коштів, інструменти для дослідження учасників, інструменти судової практики, практики АМКУ, практики органів моніторинг. Кожен інструмент має свої особливості та можливості. Якщо підібрати правильний сервіс можна знайти потрібну інформацію, чи отримати бажаний результат набагато швидше і якісніше. Водночас окремі інструменти, як свідчить практика, мають функціональні недоліки, які необхідно досліджувати і виправляти.

\section{Список використаних джерел}

1. Щодо інформаційних джерел та аналітичних інструментів у сфері публічних закупівель: лист Міністерства економічного розвитку і торгівлі України № 3305-04/17934-03 від 25.04.2019. URL: https://me.gov.ua/InfoRez/DocumentsList?id=f2e30594-ba6c-420f-9c24-2a852 415a884\&tag=InforezKnowledgeDb\&lang=uk-UA\&fNum=3305-04\%2F17934-03 (дата звернення: 10.09.2020).

2. Мулик Т. О., Здирко Н. Г. Методичний інструментарій аналізу публічних закупівель. Ефективна економіка. 2020. № 3. URL: http://www.economy.nayka.com.ua/?op=1\&z=7727 (дата звернення: 10.09.2020). DOI: $10.32702 / 2307-2105-2020.3 .68$

3. Здирко Н.Г. Державне регулювання та контроль у сфері публічних закупівель. Інститут бухгалтерського обліку, контроль та аналіз в умовах глобалізаиії: міжнародний науковий журнал. 2019. № 3-4. URL: http://ibo.tneu.edu.ua/index.php/ibo/issue/archive(дата звернення: 08.09.2020).

4. Зелінська $\mathrm{X}$. Україна стала лідером міжнародного рейтингу прозорості публічних закупівель. URL: https://ti-ukraine.org/blogs/ukrayinastala-liderom-mizhnarodnogo-rejtyngu-prozorosti-publichnyh-zakupivel/(дата звернення: 13.09.2020).

5. DOZORRO: офіційний сайт. URL: https://dozorro.org/tools.(дата звернення: 12.09.2020).

6. SIGMA (2016), Performance Measurement, Brief 21, OECD Publishing, Paris.

7. Про публічні закупівлі: Закон України від 25 грудня 2015 року №922VIII. URL: https://zakon.rada.gov.ua/laws/show/922-19 (дата звернення: 
13.09.2020).

8. Вікіпедія. URL: https://uk.wikipedia.org/wiki/Dozorro\#cite_note-12(дата звернення: 10.09.2020).

9. Публічні закупівлі. Моніторинг та його інструменти. URL: http://pravocn.org.ua/monitorynh-ta-joho-instrumenty/

10. Робота системи ризик-індикаторів та моніторинг ДАСУ. URL: https://infobox.prozorro.org/updates/robota-sistemi-rizik-indikatoriv-ta-monitoringdasu (дата звернення: 11.09.2020).

11. Про затвердження методики визначення автоматичних індикаторів ризиків, їх переліку та порядку застосування: наказ Держаудитслужби від 11.09.2018 №196. URL: https://zakon.rada.gov.ua/laws/show/z1113-18\#Техt (дата звернення: 11.09.2020).

12. Типологічне дослідження «Відмивання доходів від привласнення m коштів і майна державних підприємств та інших суб'єктів, які фінансуються за ₹ рахунок державного та місцевих бюджетів»: Наказ Державної служби กิ фінансового моніторингу України 24.12.2019 № 159. URL: https://ips.ligazakon.net/document/FN58416A. (дата звернення: 10.09.2020).

13. Про Стратегію реформування публічних закупівель («дорожню карту»): Розпорядження Кабінету Міністрів України від 24.02.2016 p. № 175 р. URL: http:// zakon.rada.gov.ua/laws/show/175-2016-\%D1\%80 (дата звернення: 10.09.2020).

14. Левон С. Б. Інструментарій забезпечення транспарентності електронних публічних закупівель в Україні. Актуальні проблеми державного управління. 2020. № 1(81). С. 50-57.

15. Ратушняк Т. В. Моніторинг публічних закупівель засобами платформи DoZorro. Економічний вісник. Серія: Фінанси, облік, оподаткування. 2018. Вип. 2. C. 162-168. URL: http://nbuv.gov.ua/UJRN/ehsfat_2018_2_24. (дата звернення: 12.09.2020).

\section{References}

1. Shchodo informatsiinykh dzherel ta analitychnykh instrumentiv u sferi publichnykh zakupivel: lyst Ministerstva ekonomichnoho rozvytku i torhivli Ukrainy [Regarding information sources and analytical tools in the field of public procurement: a letter from the Ministry of Economic Development and Trade of Ukraine] № 330504/17934-03 vid 25.04.2019 [in Ukrainian].

2. Mulyk. T. O., Zdyrko N. H. (2020) Metodychnyi instrumentarii analizu publichnykh zakupivel. [Methodical tools for public procurement analysis] Efektyvna ekonomika - Efficient economy, 3. URL: http://www.economy.nayka.com.ua/?op $=1 \& z=7727$ (data zvernennia: 10.09.2020). DOI: 10.32702/2307-2105-2020.3.68 [in Ukrainian].

3. Zdyrko. N.H. (2019) Derzhavne rehuliuvannia ta kontrol u sferi publichnykh zakupivel. [State regulation and control in the field of public procurement] Instytut 
bukhhalterskoho obliku, kontrol ta analiz $v$ umovakh hlobalizatsii: mizhnarodnyi naukovyi zhurnal. - Institute of Accounting, Control and Analysis in the context of globalization: an international scientific journal, 3-4. URL: http://ibo.tneu.edu.ua/index.php/ibo/issue/archive (data zvernennia: 08.09.2020) [in Ukrainian].

4. Zelinska. Kh. (2020) Ukraina stala liderom mizhnarodnoho reitynhu prozorosti publichnykh zakupivel [Ukraine has become the leader in the international ranking of public procurement transparency]. URL: https://tiukraine.org/blogs/ukrayina-stala-liderom-mizhnarodnogo-rejtyngu-prozorostipublichnyh-zakupivel/ (data zvernennia: 13.09.2020). [in Ukrainian].

5. DOZORRO: ofitsiinyi sait [DOZORRO:official site] URL: https://dozorro.org/tools. (data zvernennia: 12.09.2020) [in Ukrainian].

6. SIGMA (2016), Performance Measurement, Brief 21, OECD Publishing, Paris.[in French].

7. Pro publichni zakupivli: Zakon Ukrainy [On Public Procurement: Law of Ukraine] vid 25 hrudnia 2015 roku №922-VIII. URL: https://zakon.rada.gov.ua/laws/show/922-19 (data zvernennia: 13.09.2020) [in Ukrainian].

8. Vikipediia [Wikipedia]. URL: https://uk.wikipedia.org/wiki/Dozorro\#cite_ note-12 (data zvernennia: 10.09.2020) [in Ukrainian].

9. Publichni zakupivli. Monitorynh ta yoho instrumenty [Public procurement. Monitoring and its tools]. URL: http://pravocn.org.ua/monitorynh-ta-johoinstrumenty/ [in Ukrainian].

10. Robota systemy ryzyk-indykatoriv ta monitorynh DASU [Operation of the risk indicator system and monitoring of DASU]. URL: https://infobox.prozorro.org/updates/robota-sistemi-rizik-indikatoriv-ta-monitoringdasu (data zvernennia: 11.09.2020) [in Ukrainian].

11. Pro zatverdzhennia metodyky vyznachennia avtomatychnykh indykatoriv ryzykiv, yikh pereliku ta poriadku zastosuvannia [On approval of the methodology for determining automatic risk indicators, their list and procedure applied]: nakaz Derzhaudytsluzhby vid 11.09.2018 №196 [in Ukrainian].

12. Typolohichne doslidzhennia «Vidmyvannia dokhodiv vid pryvlasnennia koshtiv i maina derzhavnykh pidpryiemstv ta inshykh subiektiv, yaki finansuiutsia za rakhunok derzhavnoho ta mistsevykh biudzhetiv»" [Typological study "Money laundering from the misappropriation of funds and property of state enterprises and other entities financed by the state and local budgets"]: Nakaz Derzhavnoi sluzhby finansovoho monitorynhu Ukrainy 24.12.2019 № 159 [in Ukrainian].

13. Pro Stratehiiu reformuvannia publichnykh zakupivel («dorozhniu kartu») [On the Public Procurement Reform Strategy ("road map")]: Rozporiadzhennia Kabinetu Ministriv Ukrainy vid 24.02.2016 r. № 175 r. URL: http:// zakon.rada.gov.ua/laws/show/175-2016-\%D1\%80 (data zvernennia: 10.09.2020) [in Ukrainian]. 
14. Levon, S. B. (2020) Instrumentarii zabezpechennia transparentnosti elektronnykh publichnykh zakupivel v Ukraini [Tools for ensuring the transparency of electronic public procurement in Ukraine]. Aktualni problemy derzhavnoho upravlinnia - Actual problems of public administration, 1(81), 50-57 [in Ukrainian].

15. Ratushniak. T. V. (2018) Monitorynh publichnykh zakupivel zasobamy platformy DoZorro [Monitoring of public procurement through the DoZorro platform]. Ekonomichnyi visnyk. Seriia: Finansy, oblik, opodatkuvannia - Economic Bulletin. Series: Finance, accounting, taxation, 2, 162-168. URL: http://nbuv.gov.ua/UJRN/ehsfat_2018_2_24. (data zvernennia: 12.09.2020) [in Ukrainian].

\section{Відомості про авторів}

МУЛИк Тетяна Олексіївна - кандидат економічних наук, доцент, завідувач кафедри аналізу та статистики, Вінницький національний аграрний університет (21008, м. Вінниця, вул. Сонячна, 13, e-mail: mulyk_t_o@ukr.net).

ТОМЧУК Олена Феліксівна - кандидат економічних наук, доцент, доцент кафедри аналізу та статистики (21008, м. Вінниця, вул. Сонячна, 13, еmail:olenatomchuk@ukr.net).

МУЛИК Ярославна Ігорівна - кандидат економічних наук, доцент кафедри аудиту та державного контролю, Вінницький національний аграрний університет (21008, м. Вінниця, вул. Сонячна, 3, e-mail: mulyk.yaroslavna@ ukr.net).

MULYK Tetiana - PhD in Economics, Associate Professor, Head of the Analysis and Statistics Department, Vinnytsia National Agrarian University (21008, Vinnytsia, 13, Soniachna Str., e-mail: mulyk_t_o@ukr.net).

TOMCHUK Olena - PhD in Economics, Associate Professor, Associate Professor of analysis and statistics Department (21008, Vinnytsia, 13, Soniachna str., e-mail: olenatomchuk@ukr.net).

MULYK Yaroslavna - PhD in Economics, Associate Professor, Associate Professorof the Audit and State Control Department, Vinnytsia National Agrarian University (21008, Vinnytsia, 3, SonyachnaStr., e-mail: mulyk.yaroslavna@ukr.net).

МУЛЫК Татьяна Алексеевна - кандидат экономических наук, доцент, заведующая кафедры анализа и статистики, Винницкий национальный аграрный университет (21008, г. Винница, ул. Солнечная, 13, e-mail: mulyk_t_o@ukr.net).

ТОМЧУК Елена Феликсовна - кандидат экономических наук, доцент, доцент кафедры анализа и статистики $(21008$, г. Винница, ул. Солнечная, 13, еmail: olenatomchuk@ukr.net).

МУЛЫК Ярославна Игоревна - кандидат экономических наук, доцент кафедры аудита и государственного контроля, Винницкий национальный аграрный университет (21008, г. Винница, ул. Солнечная, 3, e-mail: mulyk.yaroslavna@ukr.net). 